\title{
General Evaluation of Hepatectomy and Hepatocellular Carcinoma Cases
}

\section{Hepatektomi ve Hepatosellüler Karsinom Olgularının Genel Değerlendirilmesi}

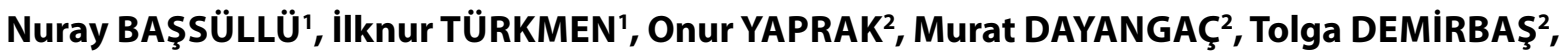 \\ Necdet GÜLER ${ }^{2}$, Süleyman URAZ ${ }^{3}$, Murat AKYILDIZ ${ }^{4}$, Engin CiĞERCiOĞULLARI ${ }^{5}$, Yaman TOKAT², \\ Yıldıray YÜZER², Gülen BÜLBÜL DOĞUSOY' \\ Departments of ${ }^{1}$ Pathology and ${ }^{4}$ Gastroenterology, istanbul Bilim University, Faculty of Medicine, ISTANBUL, TURKEY, \\ Departments of ${ }^{2}$ General Surgery Organ Transplantation and ${ }^{3}$ Gastroenterology, Şişli Florence Nightingale Hospital, iSTANBUL, TURKEY, \\ ${ }^{5}$ Department of Medical Pathology, Ağrı Maternity and Pediatric Hospital, AĞRI, TURKEY
}

Some parts of this study was presented as written posters at Intercongress meeting of the European Society of Pathology (Krakow, August 31 - September 3, 2010) and 20th National Pathology Congress (Eskişehir, September 29 - October 2, 2010).

\begin{abstract}
Objective: Although the clinical and histopathological findings of hepatocellular carcinoma are well described, there are few national studies. In this study, we aimed to investigate the relationship between these findings in total or partial hepatectomy specimens in our series.

Material and Method: We first collected 190 cases of total or partial hepatectomies performed because of hepatocellular carcinoma, cirrhosis or other disorders from the archives of Pathology. After re-examining the histopathological and clinical features such as age, gender and etiology, the relationship between them and serology results were statistically analyzed using the chi square and Multiple Comparison Tests.
\end{abstract}

Results: Among 190 cases, there were 168 (88.5\%) total and 18 (9.5\%) partial hepatectomies and $4(2 \%)$ tumorectomy or metastasectomy cases. After gross and microscopic examination, 170 (89.5\%) cases had a diagnosis of cirrhosis, 85 (44.7\%) hepatocellular carcinoma, 3 parasitic cyst, 7 metastasis, 1 hepatoblastoma, 1 hepatocellular adenoma, 2 cholangiocarcinoma, 2 Budd Chiari Syndrome, 1 focal nodular hyperplasia, 1 cavernous hemangioma, and 2 acute fulminant hepatitis.

Among the hepatocellular carcinoma cases, 53 had Hepatitis B virus, 15 Hepatitis $C$ virus , 3 Hepatitis $B$ virus and Hepatitis $C$ virus, and 3 Hepatitis B virus and Hepatitis delta virus etiology, while 6 were alcoholic and 4 were due to other causes. Among cirrhosis patients, $84(49.4 \%)$ had hepatocellular carcinoma. The male to female ratio of hepatocellular carcinoma cases was 74/11. The mean age was 55 and the median age 56.7 .

Conclusion: The results of this study demonstrated that the most common hepatic disorder was cirrhosis due to Hepatitis B virus in the hepatectomy specimens of our series that mostly consisted of total hepatectomies performed for transplantation where $50 \%$ had hepatocellular carcinoma.

Key Words: Transplantation, Cirrhosis, Hepatocellular carcinoma, Etiology

Received : 20.12.2010

Accepted : 22.06.2011

\section{ÖZ}

Amaç: Hepatosellüler karsinomların klinik ve histopatolojik özellikleri iyi tanımlanmış olmakla birlikte ülkemizdeki bulgularını yansıtan araştırma azdır. Bu çalışmada, bölümümüzdeki total ve parsiyel hepatektomi piyeslerinde klinik ve histopatolojik özellikler arasındaki ilişskiyi araştırmak amaçlanmıştır.

Gereç ve Yöntem: İlk olarak, hepatosellüler karsinom, siroz veya diğer karaciğer hastalıkları nedeniyle yapılmış 190 olguya ait total (transplantasyon) ve parsiyel hepatektomi materyalleri patoloji arşivinden toplandı. Yeniden değerlendirilen histopatolojik özellikler ile yaş, cinsiyet, etiyoloji gibi klinik ve serolojik bulgular arasındaki ilişki, istatistiksel olarak ki kare ve çok değişkenli korelasyon testi ile araştırıldı.

Bulgular: Toplam 190 olgunun 168'ini (\%88.5) total, 18'ini (\%9.5) parsiyel hepatektomi ve 4'ünü (\%2) ise tümörektomi ile metastazektomi materyalleri oluşturmaktaydı. Makroskopik ve mikroskopik incelemelerden sonra 170 olgu (\%89.5) siroz tanısı alırken; 85 (\%44.7) hepatosellüler karsinom, 1 hepatoblastom, 1 hepatosellüler adenom, 2 kolanjiokarsinom, 3 paraziter kist, 7 tümör metastazı, 2 Budd Chiari sendromu, 1 fokal noduler hiperplazi, 1 kavernöz hemangiom, 2 akut fulminant hepatit saptand.

Hepatosellüler karsinom saptanan siroz olgularının 53'ünde Hepatit $B$ virüsü, 15'inde Hepatit $C$ virüsü, 3'ünde her iki virüs birlikteliği, 3’ünde Hepatit B virüsü ve Hepatit delta virüsü birlikteliği, 6’sında alkol, 4'ünde diğer etiyolojik nedenler izlendi. Siroz olgularının 84'ünde (\%49.4) hepatosellüler karsinom saptandı. Hepatosellüler karsinom olgularında erkek kadın oranı 74/11, ortalama yaş 56.7, ortanca yaş $55 \mathrm{idi}$.

Sonuç: Bu çalışmanın sonuçları, transplantasyon amacıyla yapılan total hepatektomilerden oluşan serimizde, en sık hepatik hastalığın Hepatit B virüsüne bağlı siroz olduğunu göstermektedir ve bunların $\% 50$ ' sinde hepatosellüler karsinom mevcuttur.

Anahtar Sözcükler: Transplantasyon, Siroz, Hepatosellüler karsinom, Etiyoloji

Correspondence: Nuray BAŞSÜLLÜ

Department of Pathology, İstanbul Bilim University, Faculty of Medicine, İSTANBUL, TURKEY

E-mail: nuraybs@gmail.com Phone: +90 2122883400 


\section{INTRODUCTION}

Hepatocellular carcinoma (HCC) usually develops on the basis of chronic liver disease. The frequency of HCC is increasing in both developing and developed countries around the world and the disease has a poor prognosis (1$6)$. It is the $5^{\text {th }}$ most common tumor in the world $5^{\text {th }}$ in men and $8^{\text {th }}$ in women $(1,2)$. It ranks $3^{\text {rd }}$ among cancer-related causes of death in developing countries $(1,2)$.

Cirrhosis is the major risk factor for HCC. The incidence and etiology of HCC varies depending on geographical regions. The most important cause is hepatitis B and hepatitis $\mathrm{C}$ infections. The other major causes are alcohol, aflatoxin exposure, hereditary hemochromatosis, primary sclerosing cholangitis, autoimmune hepatitis, and cryptogenic hepatitis (3-5, 7-10).

The frequency of HCC is significantly higher in the Asia and Africa continents and the incidence is increasing $(1,2,7,10)$. $\mathrm{HBV}$ is endemic in our country and the HBV carrier rate is $5-10 \%$. The HCV incidence is reported to be $1.5 \%$ (3). The relative incidence of HCC is $1.9 \%$ in men and $1.1 \%$ in women according to data from Turkish Ministry of Health Cancer Control Department between 2004-2006 (11).

In our study, it was aimed to investigate the relationship in terms of age, gender, etiological and histopathological characteristics between specimens of total and partial hepatectomy from cases that had undergone transplantation because of HCC, cirrhosis and other chronic liver diseases and to compare our results with other studies conducted about this subject in our country and the world.

\section{MATERIAL and METHOD}

Materials from total hepatectomy cases who underwent transplantation because of HCC, cirrhosis and other chronic liver diseases, partial hepatectomies performed in order to treat HCC, metastatectomy (process of removing with intact surgical edges a metastatic tumor that has spread to the liver from a primary tumor in a different organ) and tumorectomy (process of removing a primary tumor with intact surgical edges) in our Hospital's Department of General Surgery and Transplantation between 2008-2010 were collected. 190 cases of wich pathological examinations performed by us were included in the study. Age, gender and etiological factors of the cases were retrieved from patient files. After histopathological characteristics were re-evaluated, obtained data was processed into a SPSS data table. The relationships of the findings with each other and between the clinical findings were analyzed using the Chi-square, Pearson and Multiple Comparison tests. A p value $<0,05$ was accepted as significant. Histological grade was assessed as well-differentiated grade 1, moderately differentiated grade 2 , poorly differentiated grade 3 and undifferentiated grade 4 according to the modified Edmondson and Steiner criteria (12). Pathological staging was performed according to TNM, 7th edition (12).

\section{RESULTS}

Among 190 cases, 168 (88.5\%) had total, 18 (9.5\%) partial hepatectomies and $4(2 \%)$ tumorectomy or metastasectomy. The age range of the 149 male and 41 female cases was 2 to 78 and the mean age was 53.1.

Cirrhosis was found in 170 cases (89.5\%) (Figure 1A,B and 2), HCC in 85 cases (44.7\%) (Figure $3 \mathrm{~A}, \mathrm{~B}$ and $4 \mathrm{~A}-\mathrm{D}$ ), hepatoblastoma in 1 case, hepatocellular adenoma in 1 case, cholangiocarcinoma in 2 cases, parasitic cyst in 3 cases, metastasis in 7 cases, Budd-Chiari syndrome in 2 cases, focal nodular hyperplasia and cavernous hemangioma in 1 case, and acute fulminant hepatitis in 2 cases after macroscopic and microscopic examinations (Table I).

The age range of the 62 male (72\%) and 24 female (28\%) cases who were diagnosed as cirrhosis without HCC was 12 to 72 , the mean age was 50.9 and the median age was 51 . The age range of the 74 male (87\%) and 11 female (13\%) cases (M/F ratio 6,7:1) diagnosed with HCC was 26 to 73 and the mean age was 56.7. Rate of HCC development on the basis of cirrhosis was significantly higher in males than females and between ages of 50-70 than other ages $(\mathrm{p}<0.05)$.

Among the 170 cases with cirrhosis, viral factors were detected in 123 (72.5\%), alcohol use in 16 (9.5\%), and other etiological factors in $31(18 \%)$. HBV was responsible for 87 cases (51\%), HCV for 21 cases (12\%), HBV and HCV together in 6 cases (3.5\%), HBV and hepatitis delta virus (HDV) together in 6 cases (3.5\%), and HBV infection and alcohol use in 3 cases (1.7\%) (Table II).

HCC had developed in 84 (49.5\%) of 170 cases with cirrhosis. The cause was HBV in 53 HCC-developing cirrhotic cases (62.3\%), HCV in 15 (17.6\%), both viruses together in 3, HBV and HDV together in 3, alcohol in 6 cases, and other etiological factors in 4 cases. One of the HCC cases was of the fibrolamellar type and cirrhosis was not observed table. A significant relationship was found between gender and etiology, statistically. HBV was more common in male HCC cases $(\mathrm{p}<0.05)$. The age range was 26-73, the mean age 56.1 and M/F ratio 50/3 in HCC cases with $\mathrm{HBV}$ as the etiology. The age range was 48 to 71 , the mean age 59.5 and the M/F ratio was $11 / 4$ in cases with HCV. No statistically significant difference was found between HBV and HCV by age. 

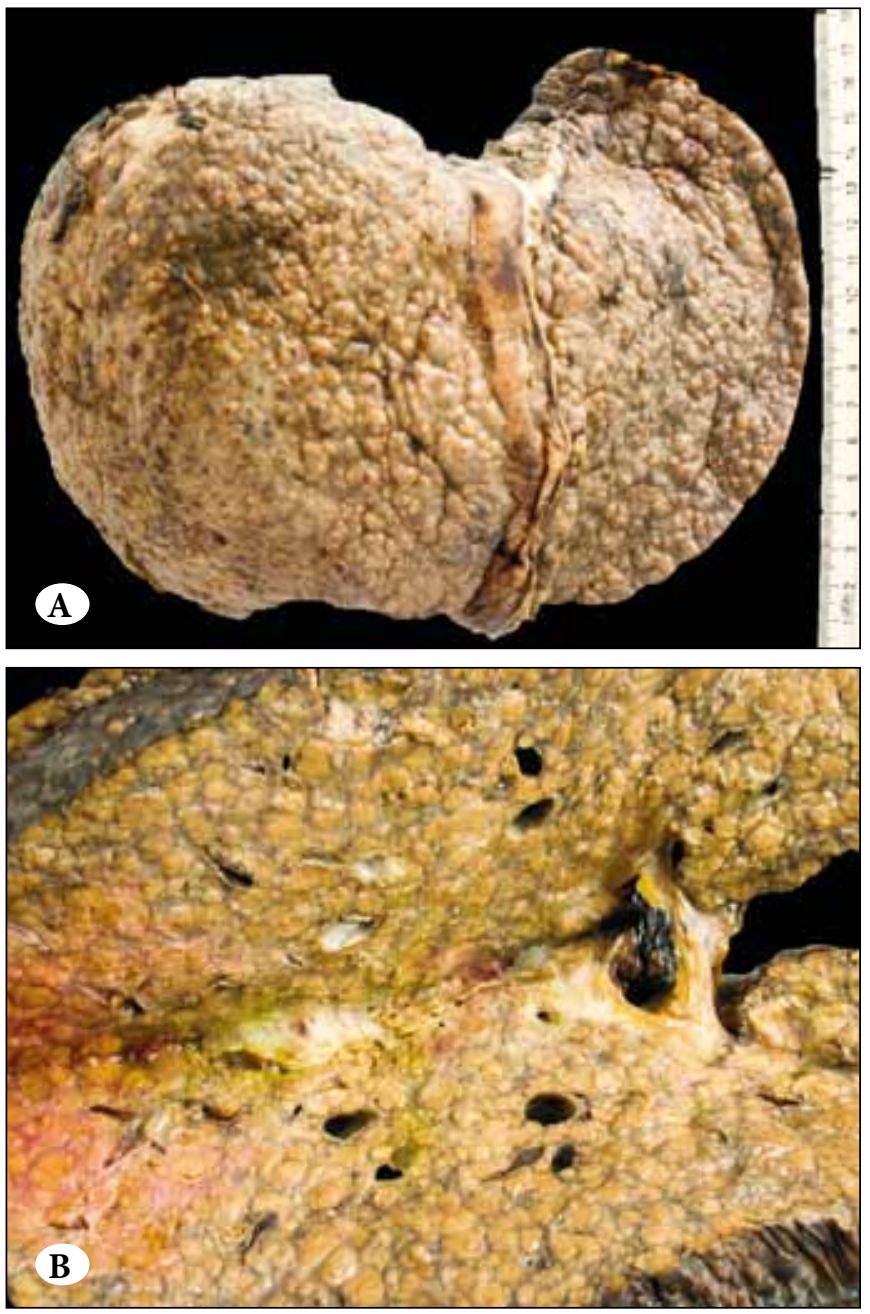

Figure 1: Macroscopic appearance of the liver in patient with cirrhosis; external surface (A) and cut section (B).

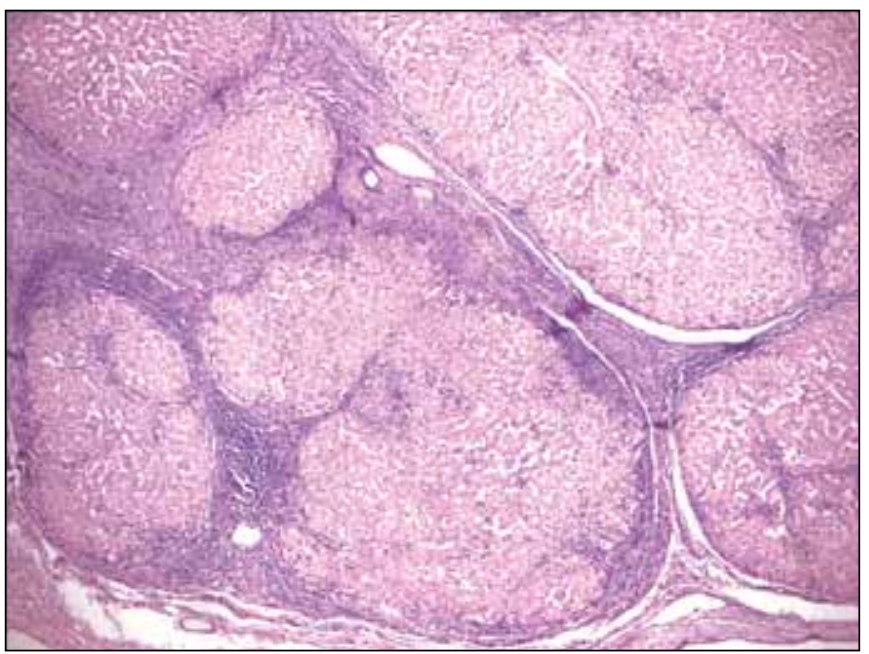

Figure 2: Microscopic appearance of cirrhosis case (H\&E; x 40).
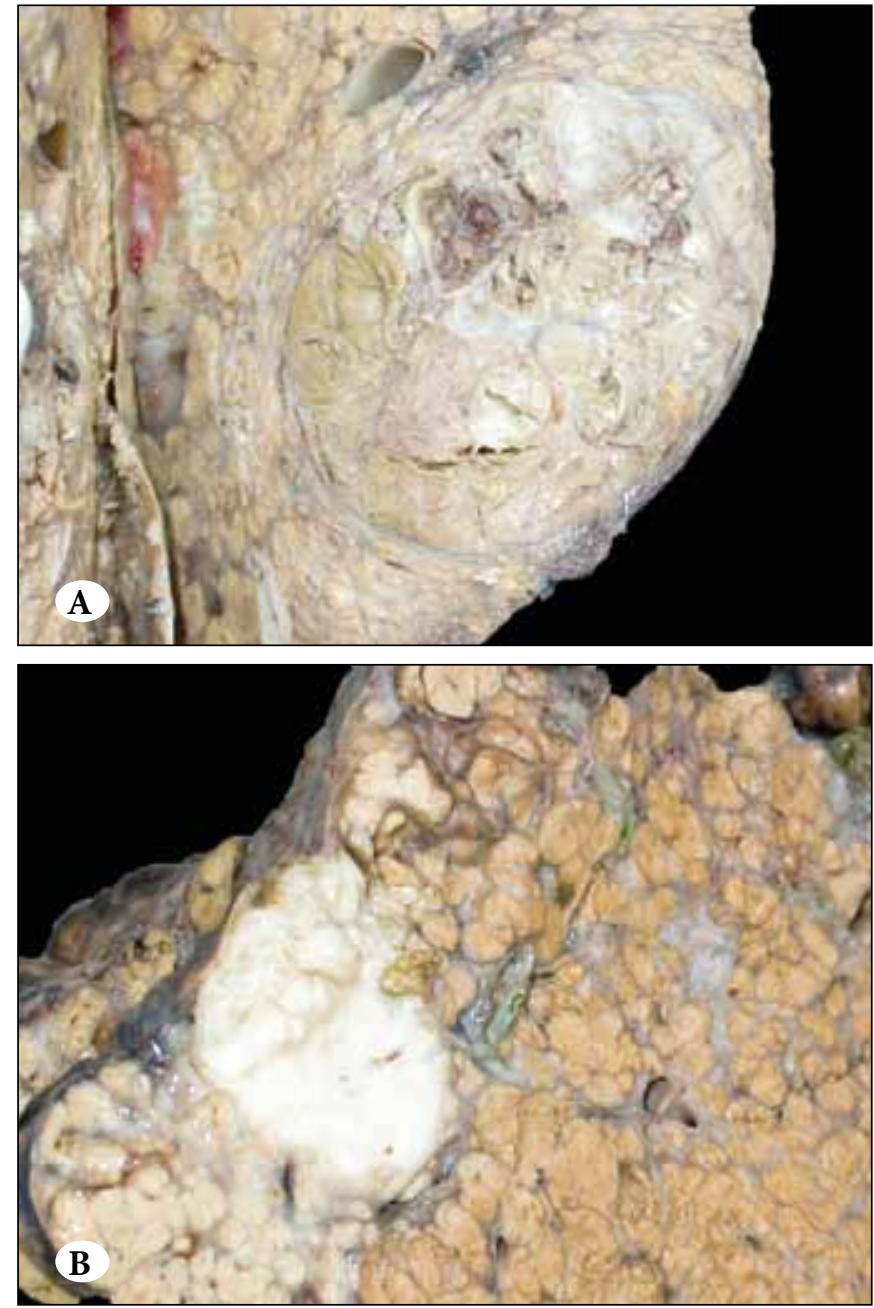

Figure 3A,B: Macroscopic appearances of hepatocellular carcinoma cases that developed on the basis of cirrhosis.

A single mass was present in $40(47 \%)$ HCC cases, and multiple masses in 45 (53\%). The largest number of masses was 8 with 2 masses present in 18 cases (21\%) and 3 or more tumoral nodules in 27 cases (32\%). A significant difference was found between age and etiology with the number of masses. HBV was more common in multiple tumors $(\mathrm{p}<0.005)$. A single nodule was more common in patients aged 50-70 $(\mathrm{p}<0.001)$.

Among HCC cases, $51(60 \%)$ were located in the right lobe, $6(7 \%)$ in the left lobe, 1 in the caudate, and 27 (32\%) located in more than one lobe. Total hepatectomy was performed in 77 cases (91\%), partial hepatectomy in $5(6 \%)$ and tumorectomy in 3 cases (3\%). A statistically significant difference was found between gender and tumor localization. The tumor was frequently located at the right lobe in male HCC cases $(\mathrm{p}<0.005)$. 

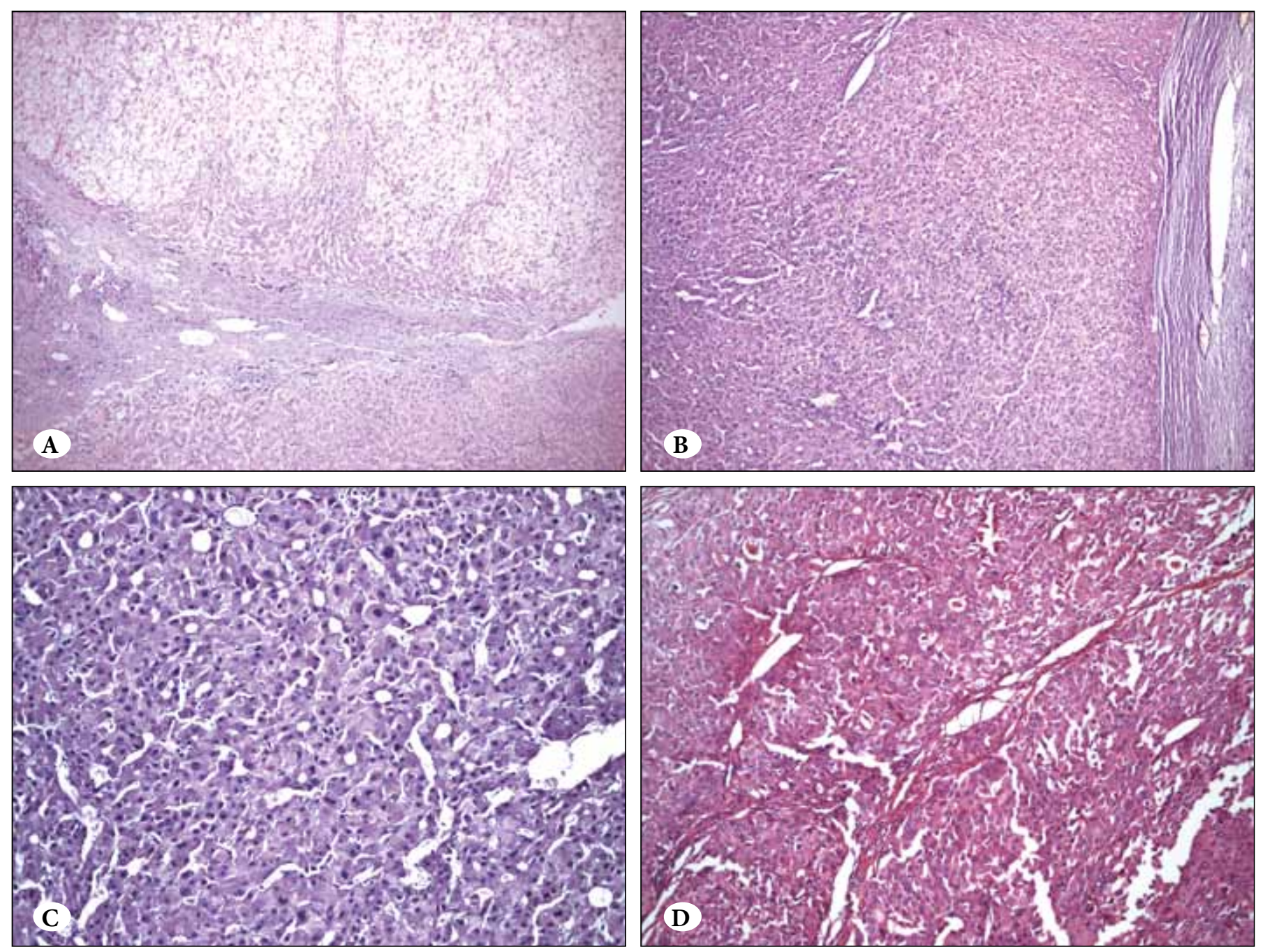

Figure 4: Microscopic appearances of hepatocellular carcinoma cases (A: Grade I, H\&E; x40, B: Grade II, H\&E; x100, C: Grade II, H\&E; x200, D: Grade III, H\&E; x200).

Table I: Demographic characteristics of the cases

\begin{tabular}{|l|c|c|c|}
\hline & Number of cases (\%) & Age range (mean) & Gender (\%) \\
\hline Hepatocellular carcinoma (HCC) & $85(44.7)$ & $26-73(53.1)$ & M: 74 (87) F: 11 (13) \\
\hline Cirrhosis (without HCC) & $86(45.2)$ & $12-72(50.9)$ & M: 62 (72) F: 24 (28) \\
\hline Metastasis & $7(3.7)$ & $23-78(59.1)$ & M: 5 (71,5) F: 2 (28.5) \\
\hline Hepatocellular adenoma & $1(0.5)$ & 19 & M: 0 F: 1 \\
\hline Hepatoblastoma & $1(0.5)$ & 2 & M:0 F: 1 \\
\hline Cholangiocarcinoma & $2(1)$ & $51-62(56.5)$ & M: 2 F: 0 \\
\hline FNH+CH & $1(0.5)$ & 40 & M: 0 F: 1 \\
\hline Parasitic cyst & $3(1.5)$ & $47-67(55.0)$ & M: 3 F: 0 \\
\hline Budd-Chiari Syndrome & $2(1)$ & $26-46(36.0)$ & M: 2 F: 0 \\
\hline Acute fulminant hepatitis & $2(1)$ & $27-33(30.0)$ & M: 0 F: 2 \\
\hline TOTAL & $\mathbf{1 9 0 ( 1 0 0 )}$ & & \\
\hline
\end{tabular}

FNH+CH: Focal Nodular Hyperplasia and Cavernous Hemangioma.

* Cirrhosis was present in 84 HCC cases. One of the HCC cases was of the fibrolamellar type and cirrhosis was not observed.

${ }^{* *}$ A total of 170 cases were diagnosed with cirrhosis (together with HCC). 86 patients had only cirrhosis. 
Table II: Etiological factors of cirrhosis and hepatocellular carcinoma cases

\begin{tabular}{|l|c|c|}
\hline Etiology & Cirrhosis N (\%) & Hepatocellular Carcinoma N (\%) \\
\hline HBV & $87(51.1)$ & $53(62.3)$ \\
\hline HCV & $21(12.3)$ & $15(17.6)$ \\
\hline HBV+HCV & $6(3.5)$ & $3(3.5)$ \\
\hline HBV+HDV & $6(3.5)$ & $3(3.5)$ \\
\hline HBV+Alcohol & $3(1.7)$ & - \\
\hline Alcohol & $16(9.5)$ & $6(7)$ \\
\hline Hemochromatosis & $2(1.1)$ & - \\
\hline Cryptogenic & $8(4.7)$ & $3(1.1)$ \\
\hline NASH & $6(3.5)$ & - \\
\hline Autoimmune & $4(2.3)$ & - \\
\hline Biliary cirrhosis & $6(3.5)$ & - \\
\hline Sclerosing cholangitis & $2(1.1)$ & - \\
\hline Wilson's Disease & $3(1.7)$ & $\mathbf{8 4}(\mathbf{1 0 0})$ \\
\hline TOTAL & $\mathbf{1 7 0 ( 1 0 0 )}$ & \\
\hline
\end{tabular}

The smallest diameter of tumor was $0,6 \mathrm{~cm}$, and the largest diameter was $27 \mathrm{~cm}$ in HCC cases and 71 cases (81\%) had tumors over $2 \mathrm{~cm}, 10$ cases (11\%) tumors between $1-2 \mathrm{~cm}$ and 4 cases (5\%) tumors smaller than $1 \mathrm{~cm}$. No statistically significant relationship was detected between diameter and other parameters except for age and stage. Tumor diameter of 1-2 cm were significantly higher in patients aged between 50-70 than the other age groups $(\mathrm{p}<0.05)$. Tumor diameter was larger in patients at an advanced stage $(\mathrm{p}<0.0001)$.

Grade 1 was detected in 11 cases (13\%), grade 2 in 35 cases (41\%), grade 3 in 15 cases (17\%), and various grade areas in 19 cases $(22 \%)$. The grade could not be evaluated in a total of 4 cases (5\%) due to severe necrosis due to radiofrequency performed in 2 cases and chemoembolization performed in 2 cases before the transplantation. Necrosis was observed in 26 HCC cases (30.5\%). As mentioned, treatmentrelated necrosis was present in nearly all of the tumor in 4 cases. Tumoral necrosis (non-therapeutic) was observed significantly more commonly in multiple tumors $(\mathrm{p}<0.05)$ and in higher grades $(\mathrm{p}<0.01)$.

When the cases were evaluated according to pathological stage (pTNM), 8 cases (9\%) were found to be stage 1, 33 cases (39\%) stage 2, 15 cases (18\%) stage 3, and 29 cases (34\%) stage 4 . The pathological stage demonstrated a statistically significant relationship with many other characteristics. HCC was detected to be at more advanced stages in males $(\mathrm{p}<0.005)$. The frequency of $\mathrm{HBV}$ was higher in patients with more advanced stages $(\mathrm{p}<0.05)$. The stage was more advanced in multiple tumors $(\mathrm{p}<0.0001)$ and in patients with right- and left-lobe involvement at the same time as expected and the diameter was significantly larger in patients at advanced stages $(\mathrm{p}<0.0001)$.

Carcinoma metastasis in regional (perihilar or portohepatic) lymph nodes was present in 3 patients (3.5\%) and tumor thrombus in the portal vein in 5 patients (5.8\%). Lymph node involvement was significantly more common in patients between the ages of 50-70 than the other age groups $(\mathrm{p}<0.005)$.

Clinical characteristics of patients other than cirrhosis and HCC is summarized in Table I and all the findings of the HCC cases and data obtained after the analyses with Pearson and Fisher's exact test are summarized in Table III.

\section{DISCUSSION}

Hepatocellular carcinoma constitutes $80 \%$ of primary liver cancers and is the $5^{\text {th }}$ most common tumor globally. It ranks $3^{\text {rd }}$ in cancer-related deaths in developing countries and the incidence is increasing around the world $(1,2,7,10,13,14)$.

The frequency and etiology of HCC show significant differences geographically. Europe and America are low risk, while Asia and Africa are high-risk regions $(1,2,7,8,13,15)$. Our country falls between these two groups $(3-6,11)$. More than $80 \%$ of HCC cases develop on the basis of cirrhotic chronic liver disease globally $(3-6,10,16-18)$. The presence of cirrhosis in the etiology of HCC has been reported as $74 \%$ and $87 \%$ in Turkey $(3,5)$. This ratio varies between 62 $75 \%$ in transplantation series $(7-10,13-22)$. It is $98.8 \%$ in our series. 
Table III: Demographic, histopathological and statistical properties of hepatocellular carcinoma cases $(\mathrm{n}=85)$

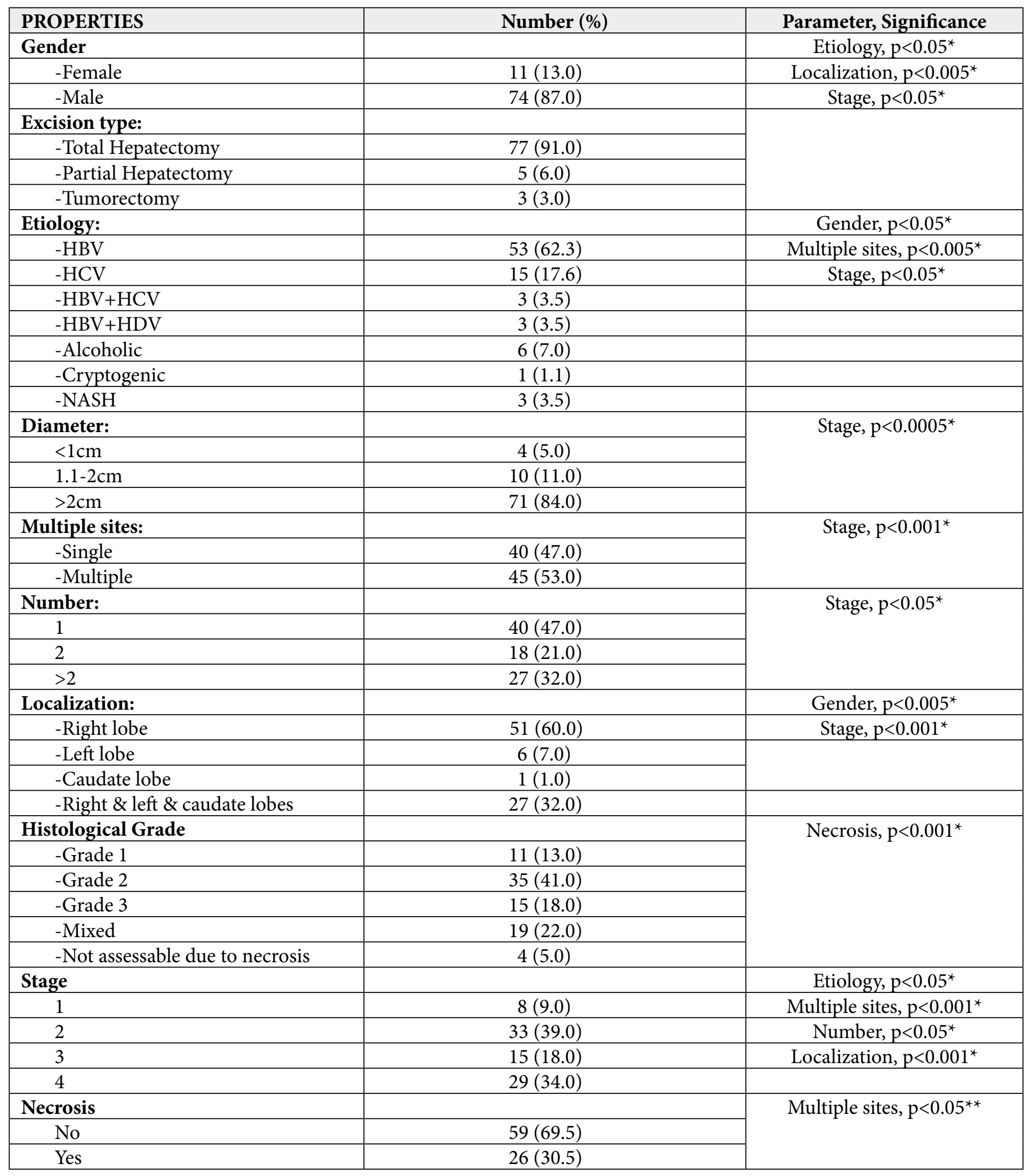

* (Pearson) ${ }^{\star \star}$ Fisher's exact test 
The rate of HCC development was reported as $15.4 \%$ in patients followed up because of cirrhosis, and 59\% and $75 \%$ in cirrhosis cases that had transplantation $(14,18)$. It was found $49.5 \%$ in our series. HCC is found in high rates in transplantation cases because these patient populations mostly consist of cases that were transplanted due to cirrhosis and HCC $(8,9,18)$.

When HCC is evaluated in terms of the risk factors in Turkey, studies indicate that viral hepatitis and HBV take first place. The rate of HBV in patients with HCC ranges from $31 \%$ to $65.7 \%$ in Turkey $(3-6,21,22)$. The HBV-related HCC rate is $95-99 \%$ in China $(10,18-20)$. It is $62.3 \%$ in our series that parallel to other studies from Turkey but is lower than the countries in the Far East.

HCV took second place with $17.6 \%$ in patients with HCC in our study and this rate varies between 11 and $28 \%$ in publications from Turkey $(3-6,21,22)$. The incidence of $\mathrm{HCV}$ is $10-12 \%$ in the Far East $(10,18-20)$. HCV is the major factor responsible with a rate of $39-77 \%$ in developed countries $(9,13,16)$.

The alcohol-related HCC rate was $7 \%$ in our series while it was $5.3-16 \%$ in other studies from our country $(3-5,21,22)$. Its rate is very high such as $25-66 \%$ in Western countries $(8,17)$.

We have determined concurrence of $\mathrm{HBV}$ and $\mathrm{HCV}$ at a rate of $3,5 \%$, concurrence of $\mathrm{HBV}$ and $\mathrm{HDV}$ at a rate of $3,5 \%$ and concurrence of $\mathrm{HBV}$ and alcohol use at a rate of $1.7 \%$ in the etiology of HCC. These findings are compatible with data from Turkey and around the world $(3-6,10,16,18,21,22)$.

HCC has been reported to be more frequent in males and at advanced ages in various studies $(3-8,16)$. $87 \%$ of HCC cases were observed in males and the $\mathrm{M} / \mathrm{F}$ ratio is $6.7: 1$, the mean age was 56.7 and the median age 55 in our study which are compatible with the literature. HBV-related HCC has been reported to be more common in males and in younger ages than HCV-related HCC $(3,4,10,18)$. Similarly, the age range of HBV-related HCC cases was 26-73, the mean age 56.1 and the M/F ratio 50/3 in our series. The age range of patients with $\mathrm{HCV}$ was $48-71$, the mean age 59.5 and the M/F ratio 11/4. However, there was no statistically significant difference between HBV and HCV in terms of age. This finding is consistent with the study of Ozer et al. (4).

A single nodule has been reported at a rate of $49-84 \%$ and more than one nodule at $25-61 \%$ in HCC cases in the literature $(4,5,8,10,15-17)$, single nodule was observed in $47 \%$ of our cases. The maximum number of masses observed in our study was 8 and 2 masses were present in $21 \%$, and 3 or more tumoral nodules in $32 \%$. Similar to the literature, $60 \%$ of our HCC cases were localized in the right lobe and $32 \%$ were localized in more than one lobe $(8,10,16,18)$.

The smallest tumor diameter was $0.6 \mathrm{~cm}$ and the biggest diameter $27 \mathrm{~cm}$ in our study; $84 \%$ of the cases had tumors over $2 \mathrm{~cm}, 11 \%$ between $1-2 \mathrm{~cm}$ and $5 \%<1 \mathrm{~cm}$ in the present study. These diameters are consistent with the tumor diameters in the literature $(4,5,10,16-18)$.

Grade 2 HCC is reported at a rate of $44-66 \%(10,13-20)$ in transplantation series; $41 \%$ of the cases were determined to be grade $2,18 \%$ grade 3 and $13 \%$ grade 1 in our series.

When cases were evaluated according to pathological stage, $9 \%$ cases were found to be stage $1,39 \%$ stage $2,18 \%$ stage 3 , and $34 \%$ stage 4 . Our data related to stages are consistent with data in our country and European countries $(5,9,17)$, while a smaller percentage cases $(8.6 \%)$ were determined to be stage 4 in the USA (16).

Carcinoma metastasis in a regional (perihilar or portohepatic) lymph node has been reported at a rate of $0-3.4 \%$ in the literature $(10,17)$ and is $3.5 \%$ in our series. The presence of tumor thrombus in the portal vein was reported at a rate of 22 and $23.5 \%(16,18)$ while this rate is very low in our study (5.8\%).

When evaluated in terms of cirrhosis, the major cause is $\operatorname{HCV}(8,9,13,15,17)$ and alcohol use $(8,13,16,17)$ in developed countries while it is HBV in Far Eastern countries and Turkey (3-6,10,18-20-22). HBV is endemic in our country and the HBV carrier rate is $5-10 \%$. The $\mathrm{HCV}$ incidence is reported to be $1.5 \%$ (3). In the study of Uzunalimoglu et al. (3), the HBV incidence was high in South, Southeast and central Anatolia while alcohol and HCV rates were found to be higher in western regions.

In a study evaluating the etiology of cirrhosis in Turkey by years, the incidence of viral hepatitis was reported to increase from $48 \%$ to 55\% between 1983 and 2001 (6). There is no national publication exactly overlapping with our transplantation study but this rate is $42.8-74 \%$ in other countries $(14,19)$. The rate is $72.5 \%$ in our study.

HBV was reported to lead to cirrhosis at a rate of $31-46 \%$, HCV 11-36\%, HDV 19\%, and concurrent HBV and HCV $0.9-3.2 \%$ in Turkey $(4,6,21,22)$. HBV has been reported at a rate of $7.4 \%$ (21) and $61.5 \%$ (14) and HCV at $35.4 \%$ (21) and $12.5 \%$ (14) in transplantation series. These rates were $51 \%$ for HBV, $12.5 \%$ for $\mathrm{HCV}, 3.5 \%$ for $\mathrm{HDV}$ and $3.5 \%$ for concurrent $\mathrm{HBV}$ and $\mathrm{HCV}$ in our study. HBV therefore 
retains its importance in the development of cirrhosis in our region and HCV still ranks 2nd after HBV in the etiology of viral hepatitis-related cirrhosis.

The alcohol-related cirrhosis rate is $16.5-25.9 \%$ in studies combining transplantation cases $(14,19)$. The contribution of alcohol to cirrhosis has been reported as $5.3-16 \%$ in our country $(4,6,21,22)$ and alcohol-related cirrhosis was observed to gradually decrease in timefrom $33 \%$ to $16 \%$ (6). It was also found to rank second as the cause of cirrhosis with a rate of $9.5 \%$ in our study.

Cirrhosis is more frequently observed in males in Turkey and the mean age has been reported to be $57.3(4,21,22)$. Cirrhosis mostly affects males at a rate of $89 \%$ and generally at a mean age of 48 to 50 in transplantation series $(14,19)$. We also found cirrhosis to be present in males at a rate of $80 \%$ and at a mean age of 54 .

In conclusion, this study indicates that cirrhosis is the most common liver disease in patients with liver transplantation, viral hepatitis is the most frequent factor in cirrhosis and HBV ranks first among the causes, and HCC develops approximately in $50 \%$ of transplanted cirrhosis cases in our center. These findings show that it is possible to control HBV hence HCC with methods of preventive medicine such as a national vaccination program. Studies including follow-up of cases, treatment responses and immunohistochemical characteristics will form the basis of projects intended to describe the biological behavior of these diseases in our country.

\section{REFERENCES}

1. Parkin M, Pisani P, Ferlay J: Estimates of the world wide incidence of 25 major cancers in 1990. Int J Cancer 1999, 80: 827-841

2. Curado MP, Edwards B, Shin HR, Storm H, Ferlay J, Heanue M: Cancer Incidence in Five Continents. Vol. IX, IARC Scientific Publications No. 160, Lyon, IARC, 2007

3. Uzunalimoglu O, Yurdaydin C, Cetinkaya H, Bozkaya H, Sahin T, Colakoglu S, Tankut E, Sarioğlu M, Ozenirler S, Akkiz H, Tozun N, Degertekin H, Okten A: Risk factors for Hepatocellular Carcinoma in Turkey. Dig Dis Sci 2001, 46: 1022-1028

4. Ozer B, Serin E, Yilmaz U, Gumurdulu Y, Saygili BO, Kayaselcuk F, Boyacioglu S: Clinicopathologic features and risk factors for Hepatocellular Carcinoma: Results from a single center in southern Turkey. Turk J Gastroenterol 2003, 14: 85-90

5. Alacacioğlu A, Somali I, Simsek I, Astarcioğlu I, Ozkan M, Camci C, Alkis N, Karaoglu A, Tarhan O, Unek T, Yilmaz U: Epidemiology and survival of Hepatocellular Carcinoma in Turkey: Outcome of multicenter study. Jpn J Clin Oncol 2008, 38:683-688
6. Ökten A: Türkiye'de kronik hepatit, siroz ve hepatosellüler karsinoma etiyolojisi. Güncel Gastroenterol 2003, 7:187-191

7. Allam N, KhalafH, Fagih M, Al-Sebayel M: Liver transplant for hepatocellular carcinoma: Experience in a Saudi population. Exp Clin Transplant 2008, 6:14-24

8. Shetty K, Timmins K, Bresinger C, Furt EE, Rattan S, Sun W, Rosen M, Soulen M, Shaked A, Reddy KR, Olthoff KM: Liver transplantation for hepatocellular carcinoma validation of present selection criteria in predict in outcome. Liver Transpl 2004, 10: 911-918

9. Mazzaferdo V, Regalia E, Doci R, Andreola S, Pulvirenti A, Bozzetti F, Montalto F, Ammatuna M, Morabito A, Gennari L: Liver transplantation for the treatment of small Hepatocellular Carcinomas in patients with cirrhosis. N Eng J Med 1996, 334 : 693-699

10. Li J, Yan LN, Yang J, Chen ZY, Li B, Zeng Y, Wen TF, Zhao JC, Wang WT, Yang JY, Xu MQ, Ma YK: Indicators of prognosis after liver transplantation in Chinese Hepatocellular Carcinoma patients. World J Gastroenterol 2009, 15: 4170-4176

11. Eser S, Olcayto E, Karakilinç H, Karaoğlanoğlu O, Yakut C, Ozalan S, Uçuncu N, Anbarcioğlu Z, Ergün A, Akin Ü, Yazici M,Ozdemir R, Ozgul N, Tuncer M: Sağlık Bakanlığı Kanserle Savaş Dairesi Başkanlığı, Epidemiyoloji ve Koruma Şube Müdürlüğü, 2004-2006 yılları Türkiye kanser insidansı. Erişim: http://www.kanser.gov.tr/folders/file/8iL-2006-SON.pdf

12. Ruby SG: Protocol for the examination of specimens from patients with Hepatocellular Carcinoma and Cholangio Carcinoma, including intrahepatic bile ducts a basis for check lists. Arch Pathol Lab Med 2000, 124: 41-45

13. Zieniewicz K, Patkowski W, Nyckowski P, Alsharabi A, Michalowicz B, Pawkal J, Pauszkiewicz R, Wroblewski T, Najnieier B, Smoter P, Hevelke P, Skwarek A, Remiszewski P, Kotulski M, Skalski M, Paczek L, Krawczyk M: Result of liver transplantation for Hepatocellular Cancer. Ann Transplant 2007, 12:11-14

14. Kuo W, Hsia CY, Loong CC, Liu CS, Tsai HL, Tseng HS, Lee RC, Tsou MY, Wu CW, Lui WY: Outcome of foreign residents undergoing deceased donor liver transplantation in China: A single-center experience in Taiwan. Liver Transpl 2009, 15: 1579-1585

15. Figueras J, Ibañez L, Ramos E, Jaurrieta E, Ortiz-de-Urbina J, Pardo F, Mir J, Loinaz C, Herrera L, López-Cillero P, Santoyo $J$ : Selection criteria for liver transplantation in early-stage Hepatocellular Carcinoma with cirrhosis: Results of a multicenter study. Liver Transpl 2001, 7: 877-883

16. Yao F, Ferrell L, Bass NM, Watson JJ, Bacchetti P, Venook A, Ascher NL, Roberts JP: Liver transplantation for hepatocellular carcinoma: Expansion of the tumor size limits does not adversely impact survival. Hepatology 2001, 33: 1394-1403

17. Jonas S, Bechstein WO, Steinmuller T, Herrmann M, Radke C, Berg T, Settmacher U, Neuhaus P: Vascular invasion and histopathologic grading determine outcome after liver transplantation for hepatocellular carcinoma in cirrhosis. Hepatology 2001, 33:1080-1086 
18. Zheng SS, Xu X, Wu J, Chen J, Wang WL, Zhang M, Liang TB, Wu LM: Liver transplantation for hepatocellular carcinoma: Hangzhou experiences. Transplantation 2008, 85: 1726-1732

19. Leung JY, Zhu AX, Gordon FD, Pratt DS, Garrigan K, Terella A, Hertl M, Cosimi AB, Chung RT: Liver transplantation outcomes for early-stage Hepatocellular Carcinoma: Results of a multicenter study. Liver Transpl 2004, 10:1343-1354

20. Li C, Wen TF, Yan LN, Li B, Yang JY, Wang WT, Xu MQ, Wei YG: Outcome of Hepatocellular Carcinoma treated by liver transplantation: comparison of living donor and deceased donor transplantation. Hepatobiliary Pancreat Dis Int 2010, 4: 366-369
21. Dinçkan A, Turkyilmaz S, Tekin A, Duman A, Yilmaz A, Mesci A, Zeki E, Hadimioğlu N, Yücetekin L, Gürkan A, Erdoğan O, Demirbaş A: Evaluation of the first 100 liver transplantations. Turk J Gastroenterol 2008, 19: 28-32

22. Yaprak O, Dayangac M, Balci D, Duran C, Uraz S, Ayanoğlu O, Yuzer Y, Tokat Y: Karaciğer nakli sonuçları üzerinde kan transfüzyonlarının etkisi ve transfüzyon gereksinimini etkileyen faktörler. İnönü Üniversitesi Tip Fakültesi Dergisi 2008, 15:87-91 